\title{
Reduction of cyanide levels in sweet cassava leaves grown in Busia County, Kenya based on different processing methods
}

\author{
Ojiambo, O. C., "Nawiri, M. P. and Masika, E. \\ Kenyatta University, P.O Box 43844-00100 Nairobi, Kenya
}

\begin{abstract}
Article history:
Received : 25 April 2017

Received in revised form : 19 May 2017

Accepted : 20 May 2017

Available Online :

14 May 2017

Keywords:

Cassava leaves

Pounding

Pounding and soaking

Cyanogenic glycoside
\end{abstract}

\section{DOI:}

http://doi.org/10.26656/ fr.2017.3.024

\begin{abstract}
Cassava (Manihot esculenta Crantz), is the third most important carbohydrate food source around the world and in particular in sub-Sahara Africa. Both the roots and leaves have dual antagonistic contribution of which; one being nutritional value and secondly, contain cyanogenic glycosides. The latter when hydrolyzed by linamarase produces poisonous hydrogen cyanide attributed to among other factors, the methods of processing. Little has been reported on processing methods and information downstream will be great given the toxicity. This report assessed the variation of cyanide levels following different processing methods of leaves of sweet cassava varieties. A number of conditions were varied to mimic affordable and as well sustainable processing methods. Processing prior to boiling for up to 25 minutes involved leaves being pounded and pounded then soaked in water. Determination of cyanide was done using picrate papers and UV-Vis spectrophotometer. The cyanide levels ranged from $576.30 \pm$ $0.32-128.34 \pm 0.34 \mathrm{mg} \mathrm{HCN}$ Equivalence/ Kg in raw cassava leaves that significantly reduced up to $88.45 \%$ with the processing's $(\mathrm{P}<0.001)$. Longer duration of boiling cassava leaves with prior processings' of pounding and that of pounding and soaking is promoted to minimize the risks associated with cyanide poisoning.
\end{abstract}

\section{Introduction}

Manihot esculenta Crantz (Cassava), the third most important carbohydrate food source around the world especially in sub-Sahara Africa, is grown in many parts of Kenya. However, the leaves are majorly consumed in Busia and Kilifi counties where they are served as a vegetable. In particular, the sweet cassava varieties are predominant in these regions. Different varieties of cassava are grouped in two main categories, with those containing up to $50 \mathrm{mg}$ $\mathrm{HCN} / \mathrm{Kg}$ (fresh weight) classified as sweet while those with above $50 \mathrm{mg} \mathrm{HCN} / \mathrm{Kg}$ (fresh weight) are in bitter category (FAO, 1990). In Busia County, sifurosa, nambamunane, maachure, adhiambolera and palisa are some of the sweet varieties grown. The plant roots and leaves are of nutritional benefit as they contain carbohydrates, proteins, vitamins, calcium and iron but are also feared as they contain cyanogenic glycosides ((United States Department of Agriculture, Agricultural Research Service, 2009).

The enzyme linamarase hydrolyzes cyanogenic glycosides to produce hydrogen cyanide, a compound that may lead to acute intoxication and even result to death particularly if levels exceed the WHO recommended minimum levels of $10 \mathrm{mg}$
$\mathrm{HCN} / \mathrm{Kg}$ body weight (Shibamoto et al., 1993). The poisonous hydrogen cyanide can lead to upper motor neuron spatic paraparesis (Konzo condition). The people in low income African countries have been associated with Konzo due to almost exclusive consumption of insufficiently processed "bitter" (high cyanide) cassava. In Kenya, there are reported incidences of intoxication and deaths as a result of consuming cassava roots. Shortly before the present work commenced, eight family members were hospitalized after consuming improperly processed cassava roots in Busia County. With information on cyanide intoxication from cassava roots, the leaves needed to be investigated as well since they are site of biosynthesis of cyanogenic glycosides (Cardoso et al., 2005).

To reduce the levels of cyanogenic glycosides and consequently that of cyanide levels, various processing methods have been reported (Lancaster et al., 1982; Bradbury, 2006; Cumbana et al., 2007). Some of the methods include manipulation of temperature through boiling, steaming, baking, frying and drying on one hand and that of reduction of $\mathrm{pH}$ through fermentation on the other. However, cassava leaves can be subjected to procedures of processing prior to their cooking. Age of the cassava 
plant, soil fertility, climatic conditions and part of the plant are among factors which affect the levels of cyanide in cassava plant (Limalevu et al., 1991; Chotineeranat et al., 2006; Rolinda et al., 2008). It was envisaged that altering the surface area of the leaves through pounding and as well a combination of pounding and soaking of leaves before varying the duration of cooking (exposure time to heat) would reduce the otherwise high levels of this poisonous compound, hydrogen cyanide. The data obtained in this research is pivotal in preventing death caused by processed cassavas leaves with enhanced cyanide levels. In addition, the communities that depend on cassava as a source of carbohydrates can adopt those methods reported herein given that they have shown reduced levels. The aim of the research was to monitor cyanide levels by varying duration of boiling unpounded, pounded and pounded then soaked leaves of sweet cassava varieties.

\section{Materials and methods}

\subsection{Sampling}

Purposive sampling of cassava varieties sifurosa, nambamunane, maachure, adhiambolera and palisa from farms in Busia County was employed. It is not within the community practice to plant different cassava varieties in the same farm thus each variety was found grown in a separate farm.

\subsection{Processing of cassava leaves}

The leaves from each variety of cassava were divided into 13 portions. Four portions of each of the cassava variety were chopped into small pieces. Ten grams $(10 \mathrm{~g})$ from each portion were weighed into different beakers containing $50 \mathrm{ml}$ of distilled water and boiled at a constant temperature of $95^{\circ} \mathrm{C}$ for 10 , 15,20 and 25 minutes respectively. After cooling, the leaves were placed between two pieces of filter papers to soak off the water then cyanide levels determined using the picrate paper. The paper was then eluted in water and the absorbance of the resulting solution determined using UV-Vis Spectrophotometer at 510 nm.

A set of five portions for each cassava variety were chopped into small pieces. 10 grams of each portion were weighed into a mortar and pounded using a pestle to form a fairly soft paste. One of the portions was analyzed raw while four of the portions were boiled. The procedure from boiling to determination of cyanide levels was as described in the earlier procedure.
Four portions of each cassava variety were chopped into small pieces and ten grams of each portion weighed into a mortar and pounded using a pestle to form a fairly soft paste which was then transferred into $150 \mathrm{ml}$ distilled water in separate beakers and soaked for 30 minutes. The procedures from boiling to determination of cyanide levels were as described in the earlier procedures.

\subsection{Determination of cyanide using picrate paper and $U V-V i s$ spectroscopy}

A round filter paper disc loaded with buffer at pH 6 was placed in a flat bottomed plastic bottle. One hundred milligrams $(100 \mathrm{mg})$ of each of the 13 portions of cassava leaves were weighed and placed on the filter paper disc and $1 \mathrm{ml}$ of distilled water added using $1 \mathrm{ml}$ plastic pipette. A yellow picrate paper attached to a plastic baking was then exposed into the plastic bottle ensuring that the paper does not touch the liquid in the bottle. The bottle was then closed and allowed to stand at room temperature for 24 hours. A blank procedure was performed. The bottles were then opened and the color of the picrate papers matched against a picrate color chart. The total amount of cyanide in leaves was read in ppm from the color chart and recorded. The picrate paper was then employed for the exact determination of cyanide using UV-Vis spectroscopy.

Five milliters $(5.0 \mathrm{ml})$ of distilled water was measured into a beaker. The plastic baking strip was removed from the picrate paper used. The picrate paper was then immersed in water in the beaker then allowed to stand for 30 minutes with occasional gentle shaking. The same procedure was done for the blank. The absorbance of the resulting picrate solution was measured at $510 \mathrm{~nm}$ against the blank as a reference. This was done in triplicate for all varieties of cassava. Total amount of cyanide was then calculated using the equation

\section{Total amount of Cynanide in ppm $=$ Absorbance x 396}

\section{Results and discussion}

The level of cyanide in unpounded boiled leaves, the pounded boiled leaves and pounded, soaked then boiled leaves are given in Tables 1-3. For the unpounded boiled leaves, levels of cyanide ranged from $128.34 \pm 0.05 \mathrm{mg} \mathrm{HCN}$ Equivalence/ $\mathrm{Kg}$ (adhiambolera) to $576.30 \pm 0.32 \mathrm{mg} \mathrm{HCN}$ Equivalence/Kg (sifurosa) before boiling (Table 1). These levels superseded the recommended levels by World Health Organization of $10 \mathrm{mg} \mathrm{HCN} / \mathrm{Kg}$ body 
Table 1. Mean levels of Cyanide in unpounded boiled leaves of sweet cassava varieties grown in Busia County, Kenya

\begin{tabular}{|c|c|c|c|c|c|c|}
\hline \multirow{2}{*}{ Cassava variety } & \multicolumn{6}{|c|}{ Boiling Time (minutes) /Cyanide levels in mg HCN Equivalence/Kg fresh weight; (Mean SE ; n = 3) } \\
\hline & $0.0 \mathrm{~min}$ & $10.0 \mathrm{~min}$ & $15.0 \mathrm{~min}$ & $20.0 \mathrm{~min}$ & $25.0 \mathrm{~min}$ & \\
\hline Sifurosa & $576.30 \pm 0.32^{\mathrm{Ee}}$ & $82.90 \pm 0.02^{\mathrm{De}}$ & $69.26 \pm 0.03^{\mathrm{Cd}}$ & $66.90 \pm 0.00^{\mathrm{Bd}}$ & $65.41 \pm 0.01^{\mathrm{Ae}}$ & $\mathrm{P}<0.001$ \\
\hline Nambamunane & $211.95 \pm 0.02^{\mathrm{Ec}}$ & $72.72 \pm 0.01^{\mathrm{Dc}}$ & $55.42 \pm 0.01^{\mathrm{Cc}}$ & $50.32 \pm 0.03^{\mathrm{Bc}}$ & $46.03 \pm 0.01^{\mathrm{Ac}}$ & \\
\hline Maachure & $146.97 \pm 0.04^{\mathrm{Eb}}$ & $67.56 \pm 0.09^{\mathrm{Db}}$ & $52.92 \pm 0.01^{\mathrm{Cb}}$ & $49.34 \pm 0.01^{\mathrm{Bb}}$ & $33.42 \pm 0.01^{\mathrm{Ab}}$ & \\
\hline Adhiambolera & $128.34 \pm 0.05^{\mathrm{Ea}}$ & $65.32 \pm 0.01^{\mathrm{Da}}$ & $50.74 \pm 0.02^{\mathrm{Ca}}$ & $42.56 \pm 0.02^{\mathrm{Ba}}$ & $30.56 \pm 0.01^{\mathrm{Aa}}$ & \\
\hline Palisa & $230.78 \pm 0.01^{\mathrm{Ed}}$ & $77.44 \pm 0.03^{\mathrm{Dd}}$ & $70.32 \pm 0.01^{\mathrm{Ce}}$ & $69.46 \pm 0.01^{\mathrm{Be}}$ & $47.03 \pm 0.01^{\mathrm{Ad}}$ & \\
\hline
\end{tabular}
$\mathrm{P}<0.001$

Mean values followed bya different capital letter within the same row differ significantly from one another and mean values followed by a different small letter within the same column differ significantly from one another (One -Way ANOVA, $\mathrm{P}<0.001$, SNK-test, $\alpha=0.05$ ).

Table 2. Mean levels of Cyanide in pounded boiled leaves of sweet cassava varieties grown in Busia County, Kenya

\begin{tabular}{|c|c|c|c|c|c|c|}
\hline \multirow{2}{*}{ Cassava variety } & \multicolumn{6}{|c|}{ Boiling Time (minutes) /Cyanide levels in mg HCN Equivalence/Kg fresh weight; (Mean SE ; $\mathrm{n}=3$ ) } \\
\hline & $0.0 \mathrm{~min}$ & $10.0 \mathrm{~min}$ & $15.0 \mathrm{~min}$ & $20.0 \mathrm{~min}$ & $25.0 \mathrm{~min}$ & \\
\hline Sifurosa & $576.30 \pm 0.32^{\mathrm{Ee}}$ & $55.21 \pm 0.00^{\mathrm{De}}$ & $51.29 \pm 0.01^{\mathrm{C}} \mathrm{e}$ & $41.39 \pm 0.01^{\mathrm{Be}}$ & $40.40 \pm 0.01^{\mathrm{Ae}}$ & $\mathrm{P}<0.001$ \\
\hline Nambamunane & $211.95 \pm 0.02^{\mathrm{Ec}}$ & $50.51 \pm 0.02^{\mathrm{Dd}}$ & $47.62 \pm 0.01^{\mathrm{Cd}}$ & $36.82 \pm 0.00^{\mathrm{Bd}}$ & $34.76 \pm 0.00^{\mathrm{Ad}}$ & \\
\hline Maachure & $146.97 \pm 0.04^{\mathrm{Eb}}$ & $36.05 \pm 0.01^{\mathrm{Da}}$ & $30.51 \pm 0.02^{\mathrm{Ca}}$ & $26.71 \pm 0.02^{\mathrm{Ba}}$ & $23.56 \pm 0.01^{\mathrm{Ab}}$ & \\
\hline Adhiambolera & $128.34 \pm 0.05^{\text {Еа }}$ & $42.44 \pm 0.01^{\mathrm{Dc}}$ & $40.57 \pm 0.03^{\mathrm{Cc}}$ & $34.56 \pm 0.01^{\mathrm{Bc}}$ & $20.69 \pm 0.01^{\mathrm{Aa}}$ & \\
\hline Palisa & $230.78 \pm 0.01^{\mathrm{Ed}}$ & $41.36 \pm 0.01^{\mathrm{Db}}$ & $38.32 \pm 0.01^{\mathrm{Cb}}$ & $33.42 \pm 0.02^{\mathrm{Bb}}$ & $32.59 \pm 0.00^{\mathrm{Ac}}$ & \\
\hline
\end{tabular}

Mean values followed bya different capital letter within the same row differ significantly from one another and mean values followed by a different small letter within the same column differ significantly from one another (One -Way ANOVA, $\mathrm{P}<0.001$, SNK-test, $\alpha=0.05$ ).

weight but falling within the range of 1 to $2000 \mathrm{mg}$ $\mathrm{HCN} / \mathrm{Kg}$ as reported by the International Center for Tropical Agriculture for cassava varieties (FAO/ WHO, 1991; CIAT, 2007). This though would not be alarming since the cassava leaves are not consumed in the raw form.Although the varieties were obtained from the same region, they were found to contain significantly different levels of cyanide $(\mathrm{P}<0.001)$ possibly due to age of the cassava plant, soil fertility among others (Limalevu et al., 1991; Chotineeranat et al., 2006; Rolinda et al., 2008).Boiling of unpounded leaves for all cassava varieties lead to a reduction in the cyanide levels.

The reduction in levels of cyanide was observed to increase as the boiling time increased from 10 minutes to 25 minutes. For the sifurosa variety, cyanide levels reduced by $85.62 \%, 87.98 \%, 88.39 \%$ and $88.65 \%$ when boiled for 10, 15, 20and 25 minutes respectively. The reductions were $65.69 \%, 73.85 \%$, $76.26 \%$ and $78.28 \%$ for nambamunane variety, $54.03 \%, 63.40 \%, 66.43 \%$ and $77.26 \%$ for maachure variety, $49.10 \%, 60.46 \%, 66.84 \%$ and $76.19 \%$ for adhiambolera variety, 66.44\%, 69.53\%, 69.90\% and $79.62 \%$ for palisa variety.

It is worth noting however that despite the reductions of up to $88.65 \%$ after 25 minutes of boiling, the cyanide levels retained were still found to be higher than those recommended by WHO (10 mg HCN/Kg body weight). This can be attributed to the surface area/volume ratio of the unpounded leaves which would hinder the interaction between cyanogenic glycosides (linamarin) and the enzyme linamarase (Cardoso et al., 2005).

For the pounded boiled leaves, the cyanide levels as boiling proceeded is reduced but greater than that of when unpounded leaves were boiled reported in Table 2. This is due to the fact that pounding leaves promotes rapid breakdown of cyanogenic glycosides given that it raptures cell compartments thus allowing direct contact between linamarin and enzyme linamarase that catalyzes the hydrolytic breakdown (Cardoso et al., 2005). For this processing, the sifurosa variety, cyanide levels reduced by $90.42 \%$, $91.10 \%, 92.82 \%$ and $92.99 \%$ when boiled for 10 , 15,20 and 25 minutes respectively. The reductions were $76.17 \%, 77.53 \%, 82.63 \%$ and $83.60 \%$ for nambamunane variety, $75.47 \%, 79.24 \%, 81.83 \%$ and $83.97 \%$ for maachure variety, $66.93 \%, 68.39 \%$, $73.07 \%$ and $83.87 \%$ for adhiambolera variety, $82.08 \%, 83.40 \%, 85.52 \%$ and $85.88 \%$ for palisa variety. This difference in ability of different cassava varieties to lose cyanide can be attributed to the difference in their cellular structure which affects the movement of substances across it.

Table 3 shows that all the cassava varieties processed by pounding, soaked then boiled recorded a higher reduction in cyanide levels compared to when processed by the earlier mentioned methods. 
Table 3. Mean levels of Cyanide in pounded, soaked then boiled leaves of sweet cassava varieties grown inBusia County, Kenya

\begin{tabular}{|c|c|c|c|c|c|c|}
\hline \multirow{2}{*}{ Cassava variety } & \multicolumn{6}{|c|}{ Boiling Time (minutes) /Cyanide levels in mg HCN Equivalence/Kg fresh weight; (Mean SE ; n = 3) } \\
\hline & $0.0 \mathrm{~min}$ & $10.0 \mathrm{~min}$ & $15.0 \mathrm{~min}$ & $20.0 \mathrm{~min}$ & $25.0 \mathrm{~min}$ & \\
\hline Sifurosa & $576.30 \pm 0.32^{\mathrm{Ee}}$ & $42.07 \pm 0.01^{\mathrm{Dd}}$ & $32.83 \pm 0.04^{\mathrm{Cb}}$ & $32.11 \pm 0.00^{\mathrm{Be}}$ & $31.40 \pm 0.01^{\mathrm{A}} \mathrm{e}$ & $\mathrm{p}<0.001$ \\
\hline Nambamunane & $211.95 \pm 0.02^{\mathrm{Ec}}$ & $48.03 \pm 0.02^{\mathrm{De}}$ & $41.32 \pm 0.00^{\mathrm{Ce}}$ & $30.63 \pm 0.02^{\mathrm{Bc}}$ & $30.23 \pm 0.01^{\mathrm{Ad}}$ & \\
\hline Maachure & $146.97 \pm 0.04^{\mathrm{Eb}}$ & $31.10 \pm 0.01^{\mathrm{Da}}$ & $28.23 \pm 0.01^{\mathrm{Ca}}$ & $24.44 \pm 0.01^{\mathrm{Ba}}$ & $19.41 \pm 0.02^{\mathrm{Ab}}$ & \\
\hline Adhiambolera & $128.34 \pm 0.05^{\text {Еa }}$ & $38.01 \pm 0.01^{\mathrm{D}} \mathrm{c}$ & $36.48 \pm 0.01^{\mathrm{Cd}}$ & $31.23 \pm 0.01^{\mathrm{Bd}}$ & $18.52 \pm 0.01^{\mathrm{Aa}}$ & \\
\hline Palisa & $230.78 \pm 0.01^{\mathrm{Ed}}$ & $37.24 \pm 0.03^{\mathrm{Db}}$ & $34.52 \pm 0.01^{\mathrm{Cc}}$ & $30.12 \pm 0.02^{\mathrm{Bb}}$ & $24.02 \pm 0.03^{\mathrm{Ac}}$ & \\
\hline & $\mathrm{P}<0.001$ & & & & & \\
\hline
\end{tabular}

Mean values followed bya different capital letter within the same row differ significantly from one another and mean values followed by a different small letter within the same column differ significantly from one another (One -Way ANOVA, P $<0.001$, SNK-test, $\alpha=0.05$ ).
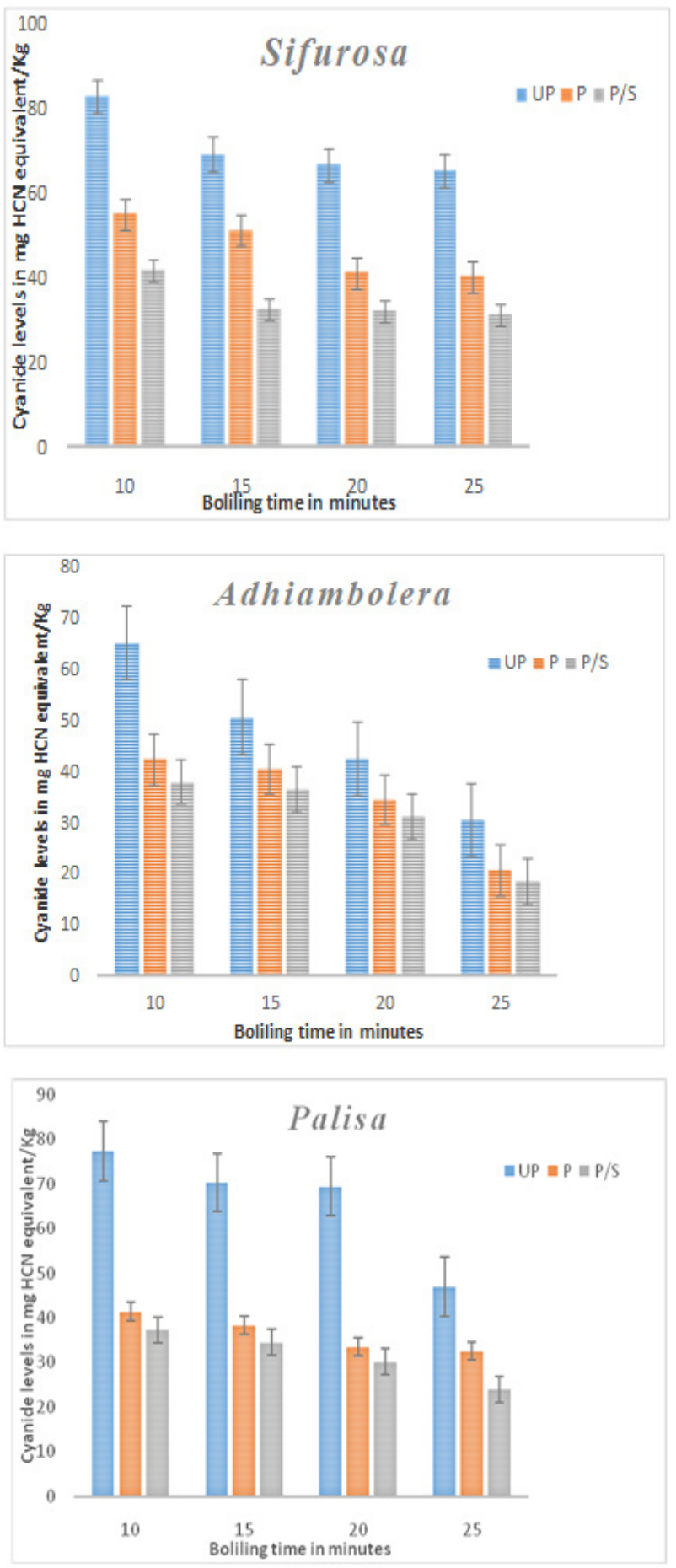
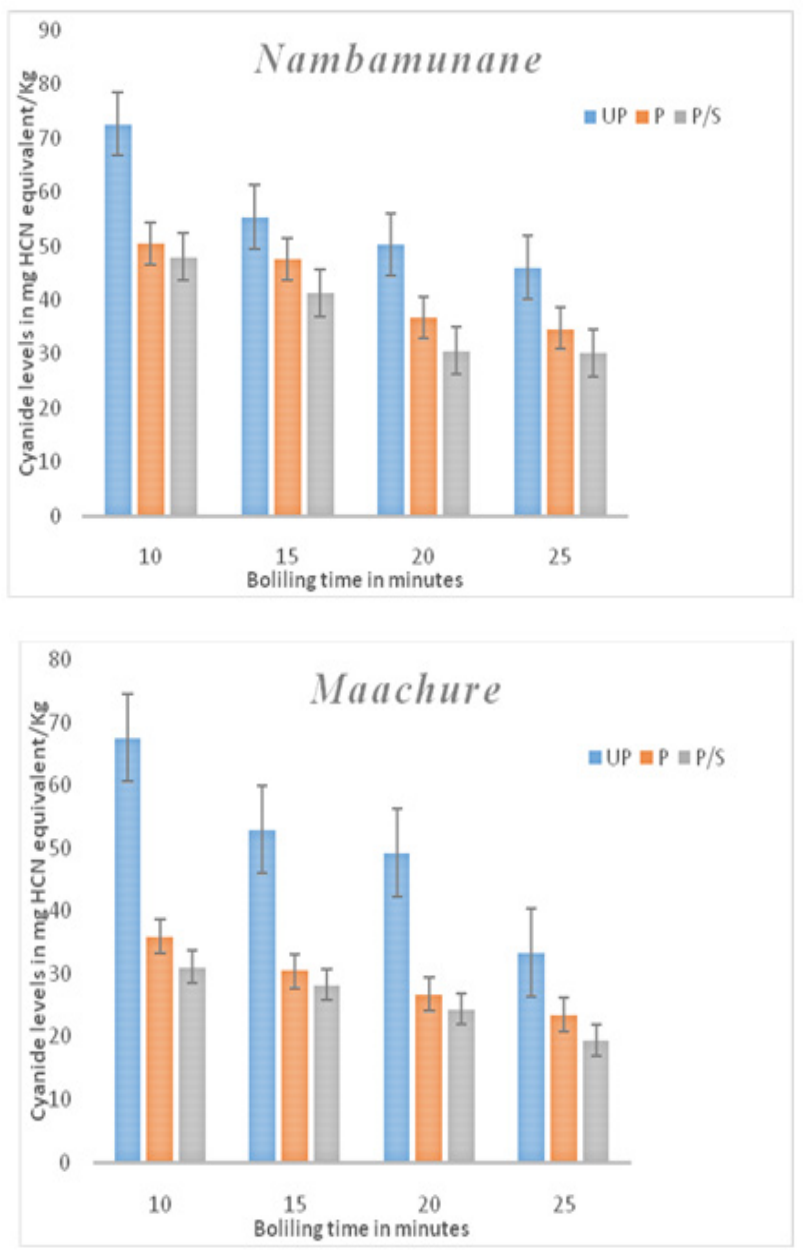

Figure 1. Effect of different processing methods on cyanide levels in different cassava varieties.

The levels of cyanide in sifurosa variety dropped from $576.30 \pm 0.32 \mathrm{mg} \mathrm{HCN}$ Equivalence $/ \mathrm{Kg}$ in raw leaves to $31.79 \pm 0.01 \mathrm{mg} \mathrm{HCN}$ Equivalence $/ \mathrm{Kg}$ when its leaves were pounded, soaked then boiled for 25 minutes compared to when processed by pounding then boiling for the same period of time where the cyanide levels reduced from $576.30 \pm 0.32 \mathrm{mg} \mathrm{HCN}$ Equivalence $/ \mathrm{Kg}$ raw leaves to $40.40 \pm 0.01 \mathrm{mg} \mathrm{HCN}$ Equivalence/Kg. When the same leaves were boiled for 25 minutes without pounding the cyanide levels reduced from $576.30 \pm 0.32 \mathrm{mg}$ HCN Equivalence/ 
$\mathrm{Kg}$ when raw to $65.41 \pm 0.01 \mathrm{mg} \mathrm{HCN}$ Equivalence/ $\mathrm{Kg}$.

These results are comparable to those reported by Bradbury (2014) when mild methods were used to remove cyanogens from cassava leaves of four different cultivars by pounding, then boiling them for between 1-20 minutes. The high reduction in cyanide levels when leaves are pounded, soaked then boiled is attributed to the fact that pounding promotes rapid breakdown of cyanogenic glycosides by rupturing cell compartments thus allowing direct contact between linamarin and the enzyme linamarase that catalyzes the hydrolytic breakdown (Cardoso et al., 2005). During soaking cyanogenic glycosides are removed by solubilization into water while during boiling heat speeds up the evaporation of hydrogen cyanide and cyanohydrins (Bokonga et al., 1994). The percentage reduction in cyanide levels is not similar in all the cassava varieties. For instance when calculated from Table 3, for the sifurosa variety, cyanide levels reduced by $92.70 \%, 94.30 \%, 94.43 \%$ and $94.55 \%$ when boiled for $10,15,20$ and 25 minutes respectively. The reductions were $77.34 \%$, $80.50 \%, 85.55 \%$ and $85.74 \%$ for nambamunane variety, $78.84 \%, 80.79 \%, 83.37 \%$ and $86.79 \%$ for maachure variety, $70.38 \%, 71.58 \%, 75.67 \%$ and $85.57 \%$ for adhiambolera variety, $83.86 \%, 85.04 \%$, $86.95 \%$ and $89.59 \%$ for palisa variety.

Heat speeds up the evaporation of hydrogen cyanide and cyanohydrins hence the leaves would not contain free cyanides and cyanohydrins explaining the reductions observed (Bokonga et al., 1994). However, it can be observed that the different cassava varieties had different ability of losing cyanide when exposed to the same processing method and boiled for the same period of time (Figure 1). These general reductions were noted to be highest during the first 10 minutes of boiling. This was possibly due to the fact that as the leaves are heated, the temperature rises and at $55^{\circ} \mathrm{C}$, the activity of linamarase enzyme is optimum thus removing a significant amount of cyanide through catalytic hydrolysis (Nambisan, 1994). As heating continues, the temperature rises and at about $100^{\circ} \mathrm{C}$, linamarase enzymes are denatured therefore linamarin starts to accumulate in the leaves. With continued heating, cyanide reduction is depended on the solubilization into the water and evaporation. Thus an increase in boiling time increases the contact time between cyanide, water and heat (Bokonga et al., 1994). This varying degree of cyanide reduction in different cassava varieties can be attributed to the difference in their cellular structures that affects diffusion of substances like the cyanogenic glycosides (Cardoso et al., 2005). All the three processing methods reduced cyanide levels in all the sweet cassava varieties studied. The extent of reduction was highest when pounded leaves were boiled compared to unpounded leaves (Figure 1).

\section{Conclusion}

Cassava leaves from Busia County contained cyanide levels that were higher than the recommended WHO levels when raw and these were significantly reduced by boiling more so by the duration of boiling. That notwithstanding longer duration of boiling the leaves with prior processings' of pounding and that of pounding and soaking is promoted to minimize the risks associated with cyanide poisoning.

\section{Acknowledgments}

The authors are grateful to Dr. Howard Bradbury (Australia International University) for providing the picrate paper kit and Kenyatta University for laboratory space at the department of Chemistry.

\section{References}

Bokanga, M., Ekanayake, I.J., Dixon, A.G.O. and Porto, M.C.M. (1994). Genotype. Environment interactions for cyanogenic potential in cassava. Acta Horticulture, $375,131-139$.

Bradbury, J. H. (2006). Simple wetting method to reduce cyanogens content of cassava flour. Journal of Food Composition Analysis, 19, 388-393.

Bradbury, J. H. and Denton, I.C. (2014). Mild method for removal of cyanogens from cassava leaves with retention of vitamins and proteins. Food Chemistry, 158, 417-420.

Cardoso, A., Mirone, E., Ernest, M., Massza, F., Cliff, J., Haque, R. and Bradbury, J. (2005). Modification of nutritional quality of cassava through plant nutrition. Journal of Food Composition and Analysis, 18, 451461.

Centro Internacional de Agricultura Tropical (CIAT). (2007). Improved cassava for the developing world. Annual report, p. 39. Colombia: CIAT

Chotineeranat, S., Suwansichon, T., Chompreeda, P., Piyachomkwan, K., Vichukit, V., Sriroth, K. and Haruthaithanasan, V. (2006). Effect of root ages on the quality of low cyanide cassava flour from Kasetsart 50. Kasetsart Journal Natural Science, 40, 694-701.

Cumbana, A., Mirione, E., Cliff, J. and Bradbury, J. H. (2007). Reduction of cyanide content of cassava flour in Mozambique by wetting method. Journal of Food Chemistry, 101, 894-897.

Food Agriculture Organization. (1991). Joint FAO/WHO food standards programme, codex alimentarius commission XII, supplement 4. Rome: FAO. 
FAO Corporate Document Repository. Retrieved from: http://www.fao.org/docrep/t0207e/T0207E00. htm\#Contents

Lancaster, P. A., Ingrame, J. S., Lim, M. Y. and Coursey, D. G. (1982). Traditional cassava based foods. Survey of processing techniques. Economic Botany, 36, 12-45.

Limalevu, L. and Aalbersberg, W.G.L. (1991). Cyanide content in fresh and processed Fijian cassava (Manihot esculenta) cultivars. Tropical Sciences, 31, 249-256.

Nambisan, B. (1994). Evaluation of the effect of various processing techniques on cyanogen content reduction in cassava. Acta Horticulturae, 375, 193-201.

Rolinda, L., Talatal, T.L., Ma, T.P. and Loreto, I. (2008). Cyanide content of cassava cultivars at different fertility levels and stages of maturity. Department of Science and Technology - Region 10. Retrieved from: http://region 10.dost.gov.ph/index.php.

Shibamoto, T. and Bjeldanes, L.F. (1993). Introduction to food toxicology. San Diego, California: Academic Press

United States Department of Agriculture, Agricultural Research Service. (2009). USDA National Nutrient Database for Standard Reference, Release 22. Nutrient Data Laboratory Home Page. Retrieved from: https:// www.ars.usda.gov/northeast-area/beltsville-md/ beltsville-human-nutrition-research-center/nutrientdata-laboratory/docs/sr22-home-page/ 